\title{
EFFECT OF VARIOUS SYSTEMS OF TILLAGE ON WINTER BARLEY YIELD, WEED INFESTATION AND SOIL PROPERTIES
}

\author{
WOŹNIAK, A. \\ Department of Herbology and Plant Cultivation Techniques, University of Life Sciences in \\ Lublin, Akademicka 13, Poland \\ (e-mail: andrzej.wozniak@up.lublin.pl)
}

(Received 21 $1^{\text {st }}$ Nov 2019; accepted $12^{\text {th }}$ Mar 2020)

\begin{abstract}
A field experiment was performed to evaluate the yield of winter barley, weed infestation, and soil properties in various systems of tillage and crop rotation The following experimental factors were examined: tillage systems (TS): 1) CT - conventional tillage, 2) RT - reduced tillage, 3) NT - no-tillage; and crop rotation (CR): 1) winter wheat - winter barley, 2) pea - winter barley. Shallow ploughing and pre-sowing ploughing were performed in CT, cultivation in RT and glyphosate only was used in NT. The study found the highest barley grain yield in CT after pea, whereas the lowest one - in NT after wheat. A higher number and mass of weeds per $\mathrm{m}^{2}$ was determined in RT than in CT and NT systems. Also the number and mass of weeds were found to be more affected by TS than by CR. The soil sampled from NT plots contained more organic $\mathrm{C}$ than that collected from RT and CT plots, and more total $\mathrm{N}$ than soil samples collected from CT plots. Higher contents of organic $\mathrm{C}$ and total $\mathrm{N}$ were also found in the soil from plots wherein barley was sown after pea compared to the soil from plot wherein barley was grown after wheat. Keywords: crop rotation, organic carbon, soil tillage, species composition of weeds, total nitrogen
\end{abstract}

\section{Introduction}

The goal of soil tillage is to provide the best conditions for plant growth, development, and yield. Tillage systems determine soil properties (West and Marland, 2002; Tabaglio et al., 2008; Celik et al., 2011; Aziz et al., 2013), crop weed infestation (Hernández Plaza et al., 2015; Gawęda et al., 2018), water-air balance, and consequently crop yield and its quality (Ruisi et al., 2014; Montemurro and Maiorana, 2015; Rachoń et al., 2015; Woźniak and Stępniowska, 2017). Opinions on the effect of tillage systems on grain yield and weed infestation of crops are inexplicit and result mainly from various soil and weather conditions occurring during cultivation (Derpsch et al., 2010; Gruber et al., 2012; Zikeli et al., 2013). Soil tillage in the no-plough system (no-tillage, reduced tillage, strip-till) is practiced increasingly more often by farmers as it significantly reduces production costs compared to the conventional system (Haliniarz et al., 2018). Nevertheless, as reported by De Vita et al. (2007), there are strong correlations between wheat grain yield, tillage system, and total precipitation in the growing season. The no-tillage (NT) system has a positive effect on wheat grain yield when the total precipitation is low, whereas conventional tillage (CT) - when it is high. The better production effect in NT is due to the smaller evaporation of water the soil which results in its greater availability to plants (De Vita et al., 2007). Also in the study conducted by Ruisi et al. (2014), the no-tillage system ensured a higher grain yield of durum wheat after shortage of precipitation, whereas the conventional tillage system increased grain yield when water availability was sufficient. In turn, the experiment conducted by Woźniak and Kwiatkowski (2013) demonstrated a higher barley grain yield in the conventional tillage system than in reduced tillage and herbicide systems. In addition, it showed various responses of barley cultivars to the tillage system applied. In turn, López-Bellido et al. (2001) demonstrated a significant effect of tillage system on wheat grain quality. In their 
study, the conventional tillage had a more favorable effect on grain quality attributes than no-tillage, which was due to better availability of nitrogen for plants. Also in the experiment performed by Ruisi et al. (2014) the conventional tillage increased protein content of durum wheat grain, compared to the no-tillage system. In contrast, Woźniak and Stępniowska (2017) concluded that contents of protein and wet gluten in the grain as well as specific weight of the grain, and grain uniformity were affected by study years to a greater extent than by tillage systems. Tillage system was also found to differentiate the chemical composition of the grain. Conventional tillage facilitated accumulation of phytic-P and iron, reduced tillage - accumulation of calcium and manganese, whereas no-tillage - accumulation of phosphorus, potassium, magnesium, and copper. In addition, heavy rainfalls promoted the accumulation of phytic-P and copper in the grain, whereas precipitation shortages increased contents of potassium and magnesium in the grain.

Tillage system affects also the extent and structure of crop infestation with weeds. In a moderate climate, the no-plough and no-tillage systems increase the number and weight of weeds compared to the conventional system. Tillage systems influence also the species composition of weeds and their distribution in cereal stands. This, in turn, affects the competitiveness between weeds and crops, with the weeds of the upper level being more competitive to cereals than these off the ground and lower levels (Hernández Plaza et al., 2015; Woźniak, 2018). In the experiment performed by Gruber et al. (2012), a few to several times more weeds were found on plots cultivated in the no-tillage system than on these cultivated in the conventional tillage system. As reported by Hernández Plaza et al. (2015), tillage systems affect also the vertical distribution of weed seeds in the soil. The NT system promotes species with fine seeds and of high fertility, capable of germinating from soil surface. In turn CT plots are predominated by weed species having large seeds and capable of germinating from deeper soil layers. In the study conducted by Woźniak (2018), a high number of weed species belonging to the upper and middle layers of wheat crop was detected in the herbicide system (HT) than in conventional (CT) and reduced (RT) tillage systems. In the no-tillage system, weeds of the upper layer - Apera spica-venti, Papaver rhoeas and Sonchus oleraceus - spread mainly anemochorically by increasing the seedbank on soil surface. According to Koning et al. (2019), in this system weeds are eradicated with glyphosate which may form biotypes resistant to this herbicide. As claimed by Farooq et al. (2011), resistance of weeds to herbicides in the herbicide tillage system poses a problem across the world, while solution to this problem may be offered by conservation agriculture.

This study aimed to evaluate the effect of tillage systems and crop rotation on winter barley grain yield and its structure as well as on weed infestation and soil properties.

\section{Material and Methods}

\section{Experiment location and description}

A field experiment with tillage systems was established in 2007 at the Experimental Station Uhrusk belonging to the University of Life Sciences in Lublin, south-east Poland. The results presented in this manuscript were collected in the year 2018 from the 11-year CT, RT and NT systems. The experiment was established with the method of complete sub-blocks ( $6 \mathrm{~m} \times 25 \mathrm{~m}$ in size), in three replications. The following experimental factors were tested: (I) tillage systems: 1) conventional tillage (CT), 2) reduced tillage (RT) and 3) no-tillage (NT); (II) crop rotation (CR): 1) winter wheat - winter barley and 2) pea - 
winter barley. The tillage plan is presented in Table 1. Winter barley cultivar 'Titus' was sown between 20 and 30 of September, at sowing density of 400 seeds per $\mathrm{m}^{2}$.

Table 1. Scheme of soil tillage

\begin{tabular}{c|c|c|c}
\hline \multirow{2}{*}{ Crops } & \multicolumn{3}{|c}{ Tillage system (TS) } \\
\cline { 2 - 4 } & conventional tillage (CT) & $\begin{array}{c}\text { reduced tillage } \\
\text { (RT) }\end{array}$ & $\begin{array}{c}\text { no-tillage } \\
\text { (NT) }\end{array}$ \\
\hline After-harvest & $\begin{array}{c}\text { shallow ploughing, } \\
\text { depth of } 10 \mathrm{~cm}\end{array}$ & $\begin{array}{c}\text { cultivator } \\
\text { (twice) }\end{array}$ & $\begin{array}{c}\text { Glyphosate } \\
\left(360 \mathrm{~g} \mathrm{~L}^{-1}, 4 \mathrm{~L} \mathrm{ha}^{-1}\right)\end{array}$ \\
\hline $\begin{array}{c}\text { Pre-sowing } \\
\text { cultivation }\end{array}$ & $\begin{array}{c}\text { pre-sow ploughing } \\
(20 \mathrm{~cm})\end{array}$ & \multicolumn{2}{|c}{$\begin{array}{c}\text { tillage unit for pre-sowing tillage } \\
\text { (cultivator and roller) }\end{array}$} \\
\hline
\end{tabular}

\section{Soil and weather conditions}

The experiment was established on Rendzic Phaeozem (WRB, 2014), which contains $24.5 \%$ of silty fraction and $13.7 \%$ of dust fraction. The soil has slightly alkaline $\mathrm{pH}$ $(\mathrm{pH} \mathrm{KCL}=7.4)$, high contents of available phosphorus $\left(120 \mathrm{mg} \mathrm{kg}^{-1} \mathrm{P} \mathrm{dm}\right)$ and potassium (194 mg kg-1 $\mathrm{K}$ ), and a moderate content of magnesium $\left(73 \mathrm{mg} \mathrm{kg}^{-1} \mathrm{Mg}\right.$ ).

In the multi-year period of 2007-2017, the total atmospheric precipitation at the study area was $640 \mathrm{~mm}$, including $230 \mathrm{~cm}$ since November till April (cold half-year) and $410 \mathrm{~mm}$ since May to October (warm half-year). In 2018, the total annual precipitation reached $440 \mathrm{~mm}$, including $160 \mathrm{~mm}$ in the cold half-year and $280 \mathrm{~mm}$ in the warm half-year (Fig. 1). In the multi-year period, the average air temperature reached $1.8^{\circ} \mathrm{C}$ in the cold half-year and $15.6^{\circ} \mathrm{C}$ in the warm half-year. In 2018 , the air temperature was slightly higher and reached $2.0^{\circ} \mathrm{C}$ and $17.1^{\circ} \mathrm{C}$, respectively. The coldest months turned out to be January (average temperature: $-2.7^{\circ} \mathrm{C}$ ) and February $\left(-2.1^{\circ} \mathrm{C}\right)$, whereas the warmest ones - July $\left(20.2^{\circ} \mathrm{C}\right)$ and August $\left(19.3^{\circ} \mathrm{C}\right)$. The growing season at the study area spans for 210-215 days; it begins from 20 to 31 of March and ends at the beginning of November.

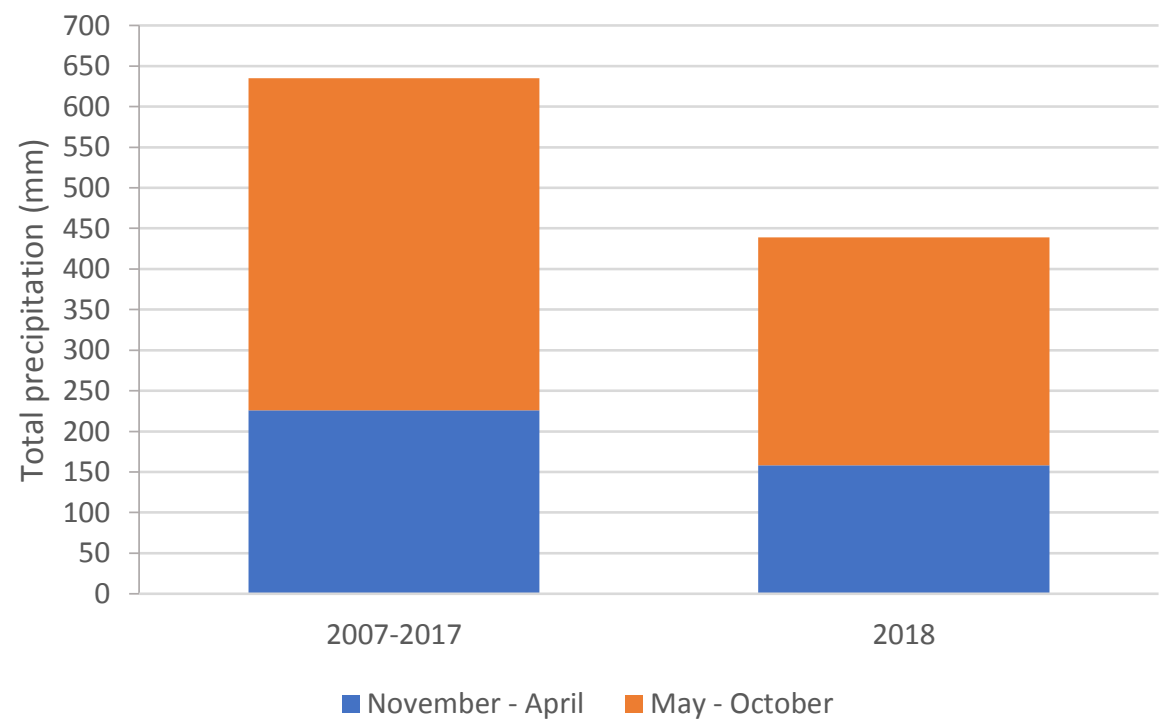

Figure 1. Total annual precipitation at the Uhrusk Experimental Station, Poland 


\section{Fertilization and plant protection}

Phosphorus-based $\left(30 \mathrm{~kg} \mathrm{ha}^{-1} \mathrm{P}\right)$ and potassium-based $\left(75 \mathrm{~kg} \mathrm{ha}^{-1} \mathrm{~K}\right)$ fertilizers were used in the autumn before winter barley sowing. Nitrogen-based fertilizers were administered in three terms: in the autumn before barley sowing $-20 \mathrm{~kg} \mathrm{ha}^{-1} \mathrm{~N}$, in the spring at the tillering stage $(23-24 \mathrm{BBCH})-50 \mathrm{~kg} \mathrm{ha}^{-1} \mathrm{~N}$, and at the heading stage (52-53 BBCH) - $20 \mathrm{~kg} \mathrm{~N} \mathrm{ha}^{-1}$ (BBCH Working Group, 2001). Fertilization doses were computed based on the chemical analysis of soil. Chemical protection of barley plants included administration of fungicides containing flusilazole + carbendazim at the shooting stage $(31-32 \mathrm{BBCH})$ and propiconazole + fenpropidin at the heading stage (43-44 $\mathrm{BBCH})$. Weeds were eradicated with a herbicide containing MCPA + mecoprop + dicamba at the tillering stage (23-24 $\mathrm{BBCH})$, and herbicide treatment was performed after the first term of assessment of weed number and species composition.

\section{Yield components and statistical analysis}

The following yield components were analysed in the experiment: 1) plant number per $\mathrm{m}^{2}$ at the tillering stage $\left.(23-24 \mathrm{BBCH}) ; 2\right)$ spike number per $\mathrm{m}^{2}$; 3) grain weight per spike; 4) 1000 grain weight; 5) number and species composition of weeds per $\mathrm{m}^{2}$ at the tillering stage (23-24 BBCH); and 6) number, species composition, and air-dry weight of weeds in $\mathrm{g} \mathrm{m}^{-2}$ at the milk maturity stage $(73-74 \mathrm{BBCH})$. Additional determinations were conducted for contents of organic carbon (C) and total nitrogen $(\mathrm{N})$ in the soil.

Grain was harvested using a plot harvester at $14 \%$ moisture content of the grain. Grain weight per spike was evaluated based on 40 plants randomly collected from each plot, whereas 1000 grain weight was determined by measuring out $2 \times 500$ grains. Weed infestation was evaluated with the botanical-gravimetric method which consists in determination of the number and species composition of weeds and of their air-dry weight from the surface area of one $\mathrm{m}^{2}$ of each plot. This surface was determined at random (twice) using a frame $(0.5 \times 1.0 \mathrm{~m})$. Determination of the air-dry weight of weeds consisted in their manual picking from frame surface, removing their root system, and placing them in a ventilated room until their constant weight has been achieved (Woźniak, 2018). Soil samples collected from all plots were determined for organic $C$ content with the Tiurin method and total $\mathrm{N}$ content with the Kjeldahl method.

Results obtained were subjected to the analysis of variance (ANOVA), whereas significance of differences between mean values for tillage systems (TS), crop rotation $(\mathrm{CR})$ and TS $\times$ CR interaction was evaluated using Tukey's HSD test, $p<0.05$.

\section{Results}

\section{Grain yield and its components}

A higher barley grain yield was determined in CT system compared to RT system (by $24.8 \%$ ) and NT (by 54.2\%) systems (Table 2). A higher barley grain yield was also noted on plots where barley was sown after pea than after winter wheat. Tillage systems (TS) and crop rotation $(\mathrm{CR})$ affected plant number per $\mathrm{m}^{2}$ (Table 3). At the $23-24 \mathrm{BBCH}$ stage, the number of barley plants per $\mathrm{m}^{2}$ was higher in CT than in RT and NT. A higher plant number was also observed on plots where barley was sown after pea than after wheat. Likewise, the number of spikes per $\mathrm{m}^{2}$ was higher in CT than in RT and NT, and on plots with barley sown after pea than after wheat. Tillage systems and crop rotation were also found to affect grain weight per spike and 1000 grain weight. Their values were more 
favourable in CT than in RT and NT, and also in plots where barley was sown after pea than after wheat.

Table 2. Grain yield of winter barley in tha $a^{-1}$

\begin{tabular}{c|c|c|c|c}
\hline \multirow{2}{*}{$\begin{array}{c}\text { Crop rotation } \\
(\mathbf{C R})\end{array}$} & $\begin{array}{c}|c| \\
\text { conventional } \\
\text { tillage }(\mathbf{C T})\end{array}$ & $\begin{array}{c}\text { reduced tillage } \\
(\mathbf{R T})\end{array}$ & $\begin{array}{c}\text { no-tillage } \\
(\mathbf{N T})\end{array}$ & \multirow{2}{*}{ Mean } \\
\cline { 2 - 4 } Winter wheat - winter barley & 4.43 & 3.38 & 1.89 & 3.23 \\
Pea - winter barley & 5.57 & 4.14 & 2.70 & 4.14 \\
Mean & 5.00 & 3.76 & 2.29 & - \\
\hline$H S D_{0.05}$ for TS $=0.24, \mathrm{CR}=0.16, \mathrm{TS} \times \mathrm{CR}=\mathrm{ns}$ & \\
\hline $\mathrm{ns}-$ not significant
\end{tabular}

Table 3. Biometric traits of winter barley

\begin{tabular}{c|c|c|c|c}
\hline \multirow{2}{*}{$\begin{array}{c}\text { Crop rotation } \\
(\mathbf{C R})\end{array}$} & \multicolumn{3}{|c|}{ Tillage system (TS) } & \multirow{2}{*}{ Mean } \\
\cline { 2 - 4 } & $\begin{array}{c}\text { conventional } \\
\text { tillage (CT) }\end{array}$ & $\begin{array}{c}\text { reduced tillage } \\
\text { (RT) }\end{array}$ & $\begin{array}{c}\text { no-tillage } \\
\text { (NT) }\end{array}$ & \\
\hline Plant number m ${ }^{-2}(23-24 \mathrm{BBCH})$ & 357 & 237 & 256 & 283 \\
\hline Winter wheat - winter barley & 383 & 281 & 269 & 311 \\
Pea - winter barley & 370 & 259 & 262 & - \\
Mean & \multicolumn{2}{|l}{}
\end{tabular}

\begin{tabular}{c|c|c|c|c}
\hline \multicolumn{5}{l}{ Spike number $\mathrm{m}^{-2}$} \\
\hline Winter wheat - winter barley & 533 & 455 & 427 & 472 \\
Pea - winter barley & 572 & 541 & 448 & 520 \\
Mean & 553 & 498 & 437 & - \\
\hline$H S D_{0.05}$ for TS $=40 ; \mathrm{CR}=27 ; \mathrm{TS} \times \mathrm{CR}=\mathrm{ns}$
\end{tabular}

$H S D_{0.05}$ for $\mathrm{TS}=40 ; \mathrm{CR}=27 ; \mathrm{TS} \times \mathrm{CR}=\mathrm{ns}$

Grain weight per spike $\mathrm{g}$

\begin{tabular}{c|c|c|c|c}
\hline Winter wheat - winter barley & 0.86 & 0.76 & 0.44 & 0.69 \\
Pea - winter barley & 1.02 & 0.77 & 0.61 & 0.80 \\
Mean & 0.94 & 0.76 & 0.53 & - \\
\hline
\end{tabular}

$H S D_{0.05}$ for $\mathrm{TS}=0.07 ; \mathrm{CR}=0.05 ; \mathrm{TS} \times \mathrm{CR}=0.12$

\begin{tabular}{c|c|c|c|c}
\hline 1000 grain weight $\mathrm{g}$ \\
\hline Winter wheat - winter barley & 48.2 & 44.6 & 43.4 & 45.4 \\
Pea - winter barley & 50.1 & 48.5 & 46.6 & 48.4 \\
Mean & 49.2 & 46.6 & 45.0 & - \\
\hline
\end{tabular}

$H S D_{0.05}$ for $\mathrm{TS}=1.6, \mathrm{CR}=1.1, \mathrm{TS} \times \mathrm{CR}=\mathrm{ns}$

ns - not significant

Variance component analysis indicates that barley grain yield, plant number per $\mathrm{m}^{2}$, spike number per $\mathrm{m}^{2}$, and grain weight per spike were affected to a greater extent by TS than by CR, whereas 1000 grain weight - to a greater extent by CR than by TS (Table 4). 
Table 4. Analysis of variance for grain yield and its components

\begin{tabular}{c|c|c|c|c}
\hline Specification & Value & $\begin{array}{c}\text { Tillage system } \\
\text { (TS) }\end{array}$ & $\begin{array}{c}\text { Crop rotation } \\
(\mathbf{C R})\end{array}$ & TS $\times$ CR \\
\hline \multirow{2}{*}{ Grain yield } & $F$ & 473.1 & 158.1 & 2.8 \\
& $p$ & $* *$ & 15,4 & $\mathrm{~ns}$ \\
\hline Plant number $\mathrm{m}^{-2}$ & $F$ & 106.4 & $* *$ & 1.7 \\
$(23-24 \mathrm{BBCH})$ & $p$ & $* *$ & 15.5 & $\mathrm{~ns}$ \\
\hline \multirow{2}{*}{ Spike number $\mathrm{m}^{-2}$} & $F$ & 29.7 & $* *$ & $\mathrm{~ns}$ \\
\hline \multirow{2}{*}{ Grain weight per spike } & $p$ & $* *$ & 27.9 & 6.2 \\
& $F$ & 131.4 & $* *$ & $*$ \\
\hline \multirow{2}{*}{1000 grain weight } & $F$ & $* *$ & 36.1 & 1.2 \\
\hline
\end{tabular}

${ }^{*} P<0.05,{ }^{* *} P<0.01, \mathrm{~ns}-$ not significant

\section{Indices of crop infestation by weeds}

At the tillering stage of winter barley (23-24 BBCH), more weeds per $\mathrm{m}^{2}$ occurred in RT than in CT and NT systems (Table 5).

Table 5. Number of weeds per $m^{2}$ in winter barley crop

\begin{tabular}{c|c|c|c|c}
\hline \multirow{2}{*}{$\begin{array}{c}\text { Crop rotation } \\
(\text { CR) }\end{array}$} & \multicolumn{2}{|c|}{ Tillage system (TS) } & \multirow{2}{*}{ Mean } \\
\cline { 2 - 4 } & $\begin{array}{c}\text { conventional } \\
\text { tillage (CT) }\end{array}$ & $\begin{array}{c}\text { reduced tillage } \\
(\text { RT) }\end{array}$ & no-tillage (NT) & \\
\hline 23-24 BBCH & 10.5 & 23.7 & 14.2 & 16.1 \\
\hline Winter wheat - winter barley & 8.9 & 15.2 & 11.0 & 11.7 \\
Pea - winter barley & 9.7 & 19.4 & 12.6 & - \\
Mean &
\end{tabular}

$H S D_{0.05}$ for $\mathrm{TS}=4.8, \mathrm{CR}=3.2, \mathrm{TS} \times \mathrm{CR}=\mathrm{ns}$

\begin{tabular}{c|c|c|c|c}
\hline $73-74$ BBCH \\
\hline Winter wheat - winter barley & 18.8 & 45.4 & 21.7 & 28.7 \\
Pea - winter barley & 13.5 & 27.5 & 15.6 & 18.9 \\
Mean & 16.2 & 36.4 & 18.6 & - \\
\hline
\end{tabular}

$H S D_{0.05}$ for $\mathrm{TS}=8.5, \mathrm{CR}=5.7, \mathrm{TS} \times \mathrm{CR}=\mathrm{ns}$

ns - not significant

The higher number of weeds was also observed on the plot where barley was sown after winter wheat than after pea. Also at the milk maturity stage of barley (73-74 BBCH) more weeds were found in RT than in CT and NT systems, and on plots where barley was sown after wheat than after pea. Similar observations were made for the air-dry weight of weeds (Table 6). The greatest biomass was developed by weeds in RT, smaller one in $\mathrm{NT}$, and the smallest one in CT system. Variance component analysis indicates that, in both terms of evaluation, the number of weeds per $\mathrm{m}^{2}$ and air-dry weight of weeds were more influenced by TS than by CR (Table 7). 
Table 6. Air-dry weight of weeds in $\mathrm{g}^{-2}$ at the 73-74 BBCH term of winter barley

\begin{tabular}{c|c|c|c|c}
\hline \multirow{2}{*}{$\begin{array}{c}\text { Crop rotation } \\
(\text { CR) }\end{array}$} & \multicolumn{3}{|c|}{ Tillage system (TS) } & \multirow{2}{*}{ Mean } \\
\cline { 2 - 4 } & $\begin{array}{c}\text { conventional } \\
\text { tillage (CT) }\end{array}$ & $\begin{array}{c}\text { reduced tillage } \\
(\mathbf{R T})\end{array}$ & $\begin{array}{c}\text { no-tillage } \\
(\mathbf{N T})\end{array}$ & 19.6 \\
Winter wheat - winter barley & 10.9 & 29.1 & 18.7 & 12.0 \\
Pea - winter barley & 5.0 & 16.7 & 14.3 & - \\
Mean & 8.0 & 22.9 & 16.5 & \\
\hline$H S D_{0.05}$ for $\mathrm{TS}=5.9, \mathrm{CR}=4.0, \mathrm{TS} \times \mathrm{CR}=\mathrm{ns}$
\end{tabular}

ns - not significant

Table 7. Analysis of variance conducted for the number and weight of weeds in winter barley

\begin{tabular}{c|c|c|c|c}
\hline Specification & Value & $\begin{array}{c}\text { Tillage system } \\
\text { (TS) }\end{array}$ & $\begin{array}{c}\text { Crop rotation } \\
\text { (CR) }\end{array}$ & TS $\times$ CR \\
\hline Number of weeds & $F$ & 15.5 & 9.1 & 2.0 \\
23-24 BBCH & $p$ & $* *$ & $\mathrm{~ns}^{*}$ & 2.5 \\
Number of weeds & $F$ & 24.1 & 14.3 & $\mathrm{~ns}$ \\
73-74 BBCH & $p$ & $* *$ & 17.2 & 1.8 \\
Air-dry weight of weeds & $F$ & 22.7 & $* *$ & $\mathrm{~ns}$ \\
$73-74$ BBCH & $p$ & $* *$ & & \\
\hline
\end{tabular}

${ }^{*} P<0.05,{ }^{* *} P<0.01$, ns - not significant

Tillage systems (TS) and crop rotation (CR) affected also the number and composition of weed species in barley stands (Table 8). At the tillering stage (23-24 BBCH), a higher number of weed species was observed on RT than on CT and NT plots, as well as on plots where barley was sown after pea than after wheat. Also at the milk maturity stage of barley (73-74 BBCH) was the number of weed species higher in RT than in CT and NT systems, and in plots where barley was sown after wheat than after pea.

Table 8. Number of weed species in winter barley crop

\begin{tabular}{|c|c|c|c|c|}
\hline \multirow{2}{*}{$\begin{array}{l}\text { Crop rotation } \\
\text { (CR) }\end{array}$} & \multicolumn{3}{|c|}{ Tillage system (TS) } & \multirow[b]{2}{*}{ Mean } \\
\hline & $\begin{array}{c}\text { conventional } \\
\text { tillage }(\mathrm{CT})\end{array}$ & $\begin{array}{c}\text { reduced tillage } \\
(\mathrm{RT})\end{array}$ & no-tillage (NT) & \\
\hline \multicolumn{5}{|l|}{$23-24 \mathrm{BBCH}$} \\
\hline Winter wheat - winter barley & 8.0 & 11.0 & 4.0 & 7.7 \\
\hline Pea - winter barley & 10.0 & 16.0 & 7.0 & 11.0 \\
\hline Mean & 9.0 & 13.5 & 5.5 & - \\
\hline \multicolumn{5}{|c|}{$H S D_{0.05}$ for $\mathrm{TS}=3.6, \mathrm{CR}=2.7, \mathrm{TS} \times \mathrm{CR}=4.4$} \\
\hline \multicolumn{5}{|l|}{ 73-74 BBCH } \\
\hline Winter wheat - winter barley & 13.0 & 22.0 & 15.0 & 16.6 \\
\hline Pea - winter barley & 10.0 & 16.0 & 8.0 & 11.3 \\
\hline Mean & 11.5 & 19.0 & 11.5 & - \\
\hline \multicolumn{5}{|c|}{$H S D_{0.05}$ for $\mathrm{TS}=4.1, \mathrm{CR}=3.7, \mathrm{TS} \times \mathrm{CR}=\mathrm{ns}$} \\
\hline
\end{tabular}


In the CT, RT, and NT systems, most of the weed species belonged to the middle and upper level of barley stand, whereas a lower number of species were representatives of the ground level weed species (Figs. 2 and 3).

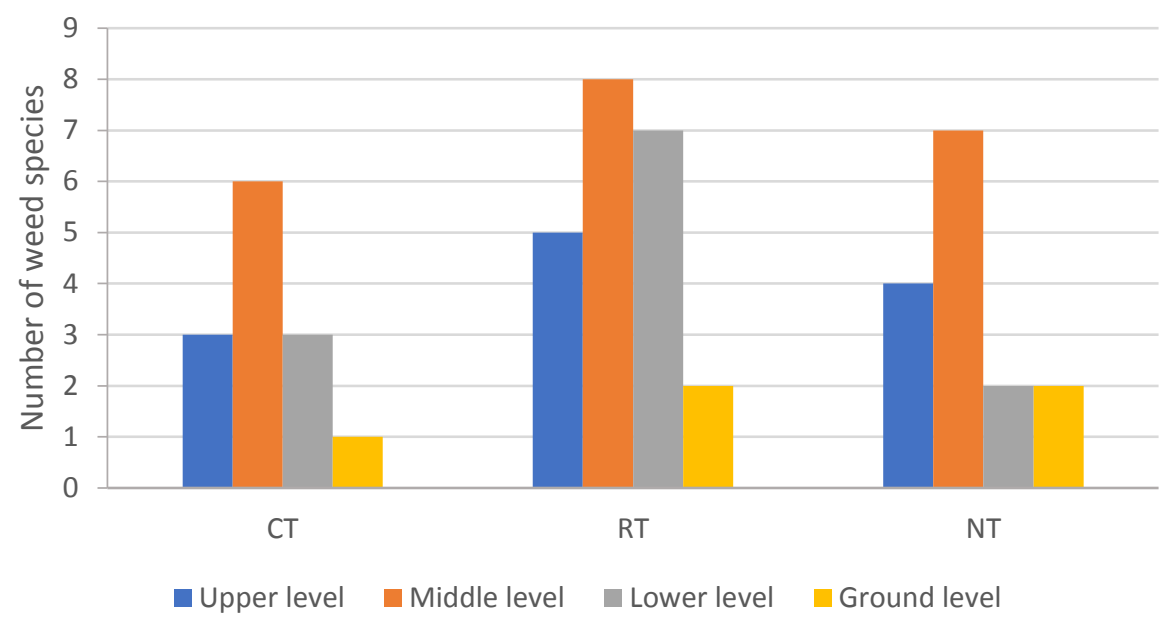

Figure 2. Level distribution of weeds in winter barley crop at the milk maturity stage of barley (73-74 BBCH) in crop rotation: winter wheat - winter barley

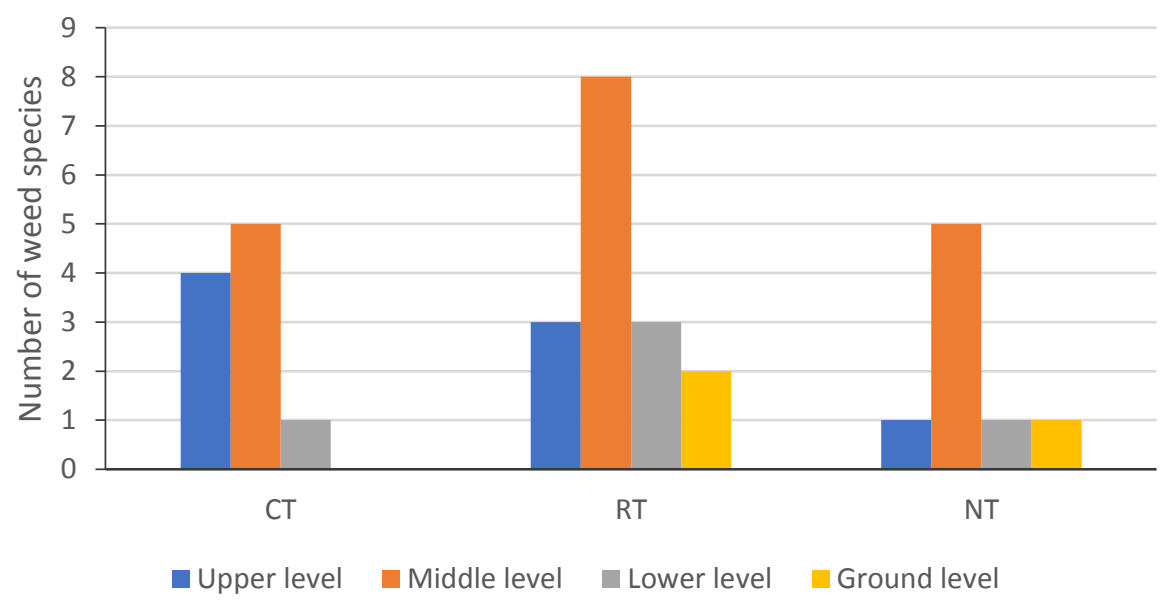

Figure 3. Level distribution of weeds in winter barley crop at the milk maturity stage of barley (73-74 BBCH) in crop rotation: pea - winter barley

At the tillering stage of barley (23-24 BBCH), the most abundant species on the plot where barley was sown after wheat included: Thlaspi arvense, Apera spica-venti and Consolida regalis in CT system, Apera spica-venti, Consolida regalis and Veronica persica in RT system as well as Consolida regalis, Thlaspi arvense and Galium aparine in NT system (Fig. 4).

The prevailing species observed on the plot with barley sown after pea included: Apera spica-venti, Papaver rhoeas and Galium aparine in CT system, Apera spica-venti, Tripleurospermum inodorum and Consolida regalis in RT system and Galium aparine, Tripleurospermum inodorum and Apera spica-venti in NT system (Fig. 5). 


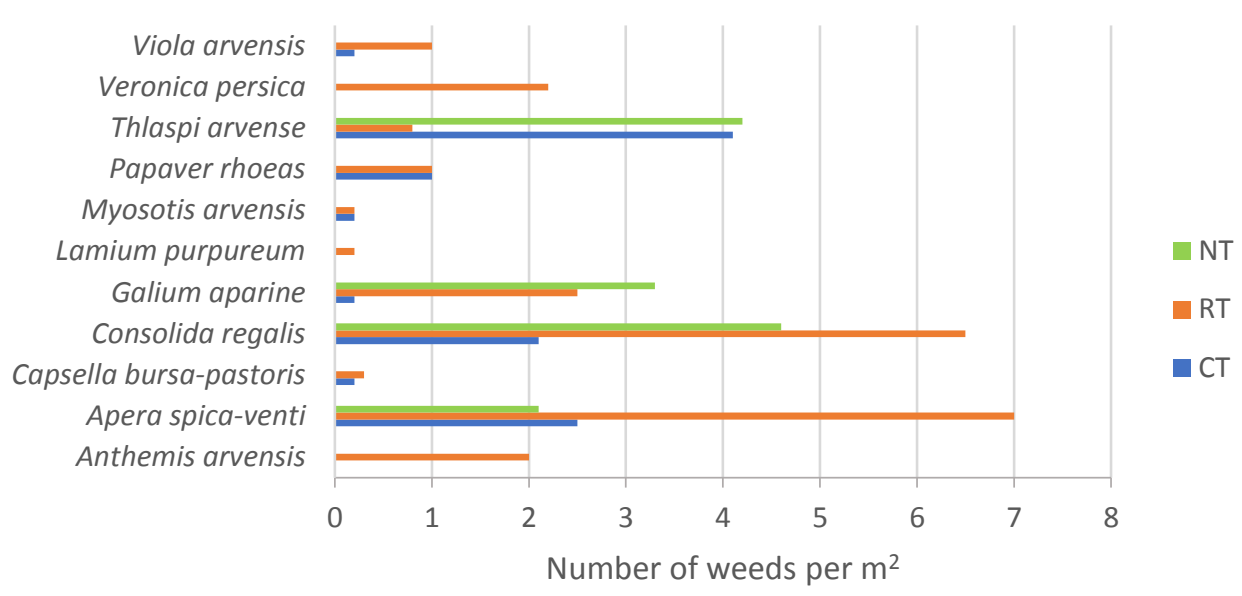

Figure 4. Species composition of weeds in winter barley crop at the tillering stage of barley (23-24 BBCH) in crop rotation: winter wheat - winter barley; $C T$ - conventional tillage, $R T-$ reduced tillage, $N T$ - no-tillage

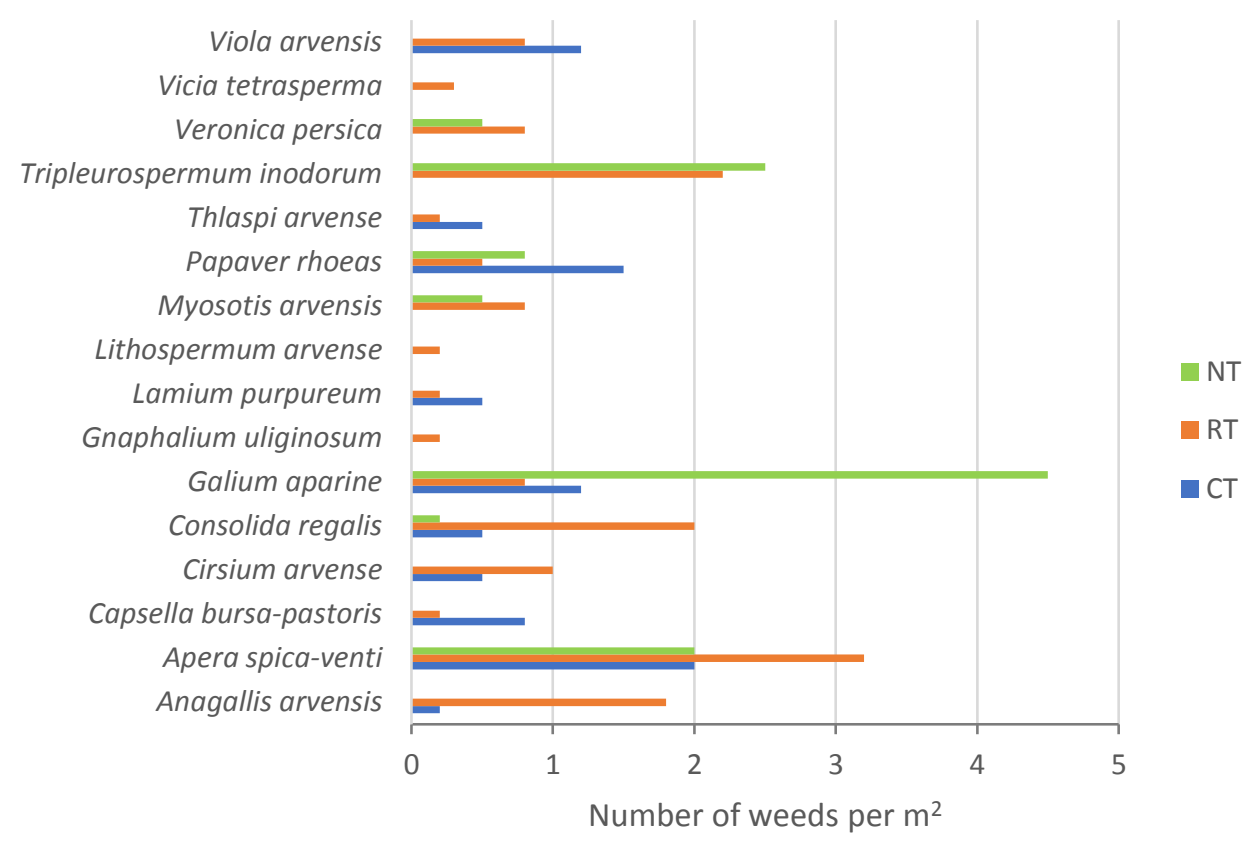

Figure 5. Species composition of weeds in winter barley crop at the tillering stage of barley (23-24 BBCH) in crop rotation: pea - winter barley; $C T$ - conventional tillage, $R T$ - reduced tillage, NT-no-tillage

At the milk maturity stage of winter barley $(73-74 \mathrm{BBCH})$, the predominating weed species observed on the plot where barley was sown after wheat included: Galeopsis tetrahit, Sinapis arvensis and Fallopia convolvulus in CT system, Apera spica-venti, Papaver rhoeas and Consolida regalis in RT system and Apera spica-venti, Consolida regalis and Galium aparine in NT system (Fig. O). 


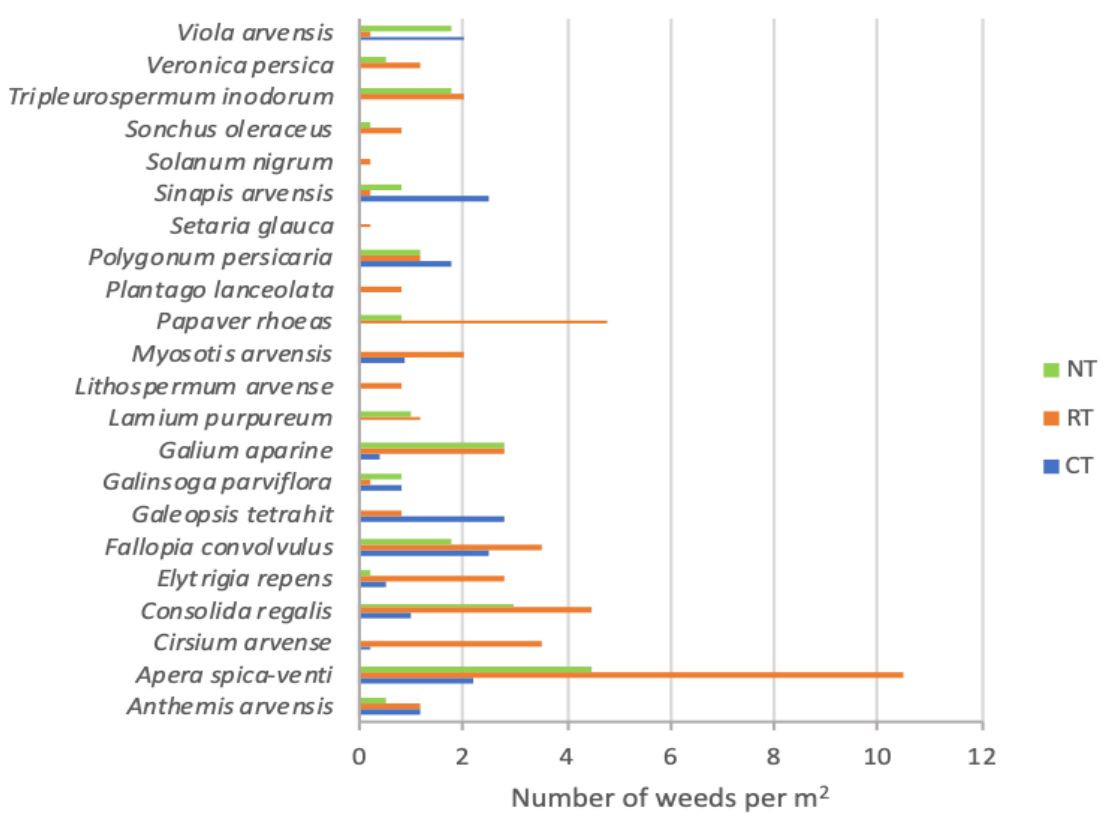

Figure 6. Species composition of weeds in winter barley crop at the milk maturity stage of barley (73-74 BBCH) in crop rotation: winter wheat - winter barley; $C T$ - conventional tillage, $R T$ - reduced tillage, $N T$ - no-tillage

On the plot where barley was sown after pea, these were: Fallopia convolvulus, Papaver rhoeas and Apera spica-venti in CT system, Apera spica-venti, Consolida regalis and Galium aparine in RT system and Apera spica-venti, Tripleurospermum inodorum and Consolida regalis in NT system (Fig. 7).

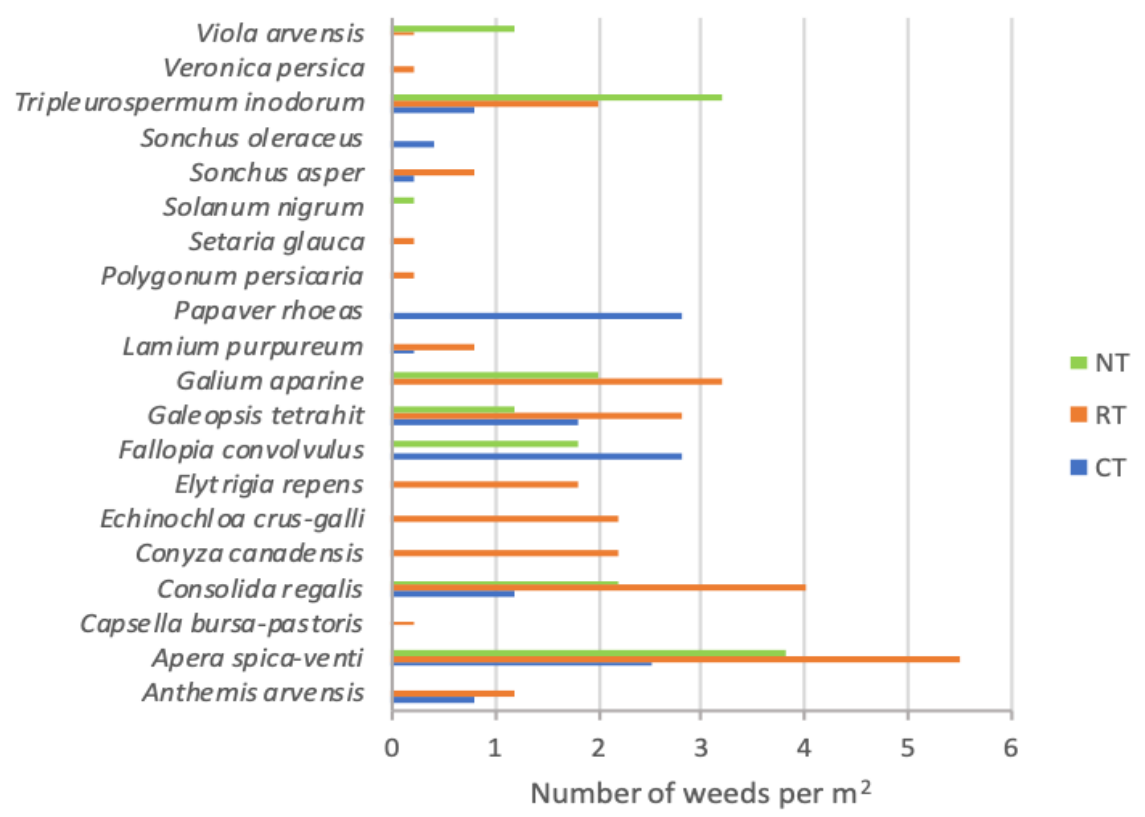

Figure 7. Species composition of weeds in winter barley crop at the milk maturity stage of barley (73-74 BBCH) in crop rotation: pea - winter barley; $C T$ - conventional tillage, $R T-$ reduced tillage, $N T$ - no-tillage 


\section{Soil properties}

The soil sampled from NT plots contained more organic $\mathrm{C}$ than that from RT and CT plots (Table 9). Also more organic $\mathrm{C}$ was determined in the soil from plots where barley was sown after pea than after wheat. In turn, total $\mathrm{N}$ content was similar in soil samples from NT and RT plots, and significantly higher in the soil from CT plots. Also a higher $\mathrm{N}$ total content was determined in the soil sampled from plots where barley was sown after pea than after wheat.

Table 9. Effect of crop rotation and tillage system on chemical properties of soil $(0-30 \mathrm{~cm})$

\begin{tabular}{|c|c|c|c|c|}
\hline \multirow{2}{*}{$\begin{array}{l}\text { Crop rotation } \\
\text { (CR) }\end{array}$} & \multicolumn{3}{|c|}{ Tillage system (TS) } & \multirow[b]{2}{*}{ Mean } \\
\hline & $\begin{array}{c}\text { conventional } \\
\text { tillage }(\mathrm{CT})\end{array}$ & $\begin{array}{l}\text { reduced tillage } \\
\text { (RT) }\end{array}$ & $\begin{array}{c}\text { no-tillage } \\
\text { (NT) }\end{array}$ & \\
\hline \multicolumn{5}{|l|}{ Organic $\mathrm{C}\left(\mathrm{g} \mathrm{kg}^{-1} \mathrm{dm}\right)$} \\
\hline Winter wheat - winter barley & 8.33 & 11.03 & 12.43 & 10.60 \\
\hline Pea - winter barley & 10.70 & 11.70 & 13.03 & 11.81 \\
\hline Mean & 9.52 & 11.37 & 12.73 & - \\
\hline \multicolumn{5}{|c|}{$H S D_{0.05}$ for $\mathrm{TS}=1.08, \mathrm{CR}=0.72, \mathrm{TS} \times \mathrm{CR}=\mathrm{ns}$} \\
\hline \multicolumn{5}{|c|}{ Total $\mathrm{N}\left(\mathrm{g} \mathrm{kg}^{-1} \mathrm{dm}\right)$} \\
\hline Winter wheat - winter barley & 0.86 & 0.94 & 0.96 & 0.92 \\
\hline Pea - winter barley & 0.91 & 1.06 & 1.08 & 1.01 \\
\hline Mean & 0.88 & 1.00 & 1.02 & - \\
\hline
\end{tabular}

ns - not significant

Variance component analysis demonstrates that organic $\mathrm{C}$ content in the soil was influenced to a greater extent by TS than by $\mathrm{CR}$, whereas total $\mathrm{N}$ content was similarly affected by CR and TS (Table 10).

Table 10. Analysis of variance for chemical properties of soil

\begin{tabular}{c|c|c|c|c}
\hline Specification & Value & $\begin{array}{c}\text { Tillage system } \\
\text { (TS) }\end{array}$ & $\begin{array}{c}\text { Crop rotation } \\
(\mathbf{C R})\end{array}$ & TS $\times$ CR \\
\hline \multirow{2}{*}{ Organic C } & $F$ & 31.89 & 13.50 & 3.08 \\
& $p$ & ${ }^{* *}$ & ${ }^{* *}$ & $\mathrm{~ns}$ \\
\hline \multirow{2}{*}{ Total N } & $F$ & 7.64 & 9.14 & 0.51 \\
& $p$ & ${ }^{* *}$ & ${ }^{*}$ & $\mathrm{~ns}$ \\
\hline
\end{tabular}

${ }^{*} P<0.05,{ }^{* * *} P<0.01, \mathrm{~ns}-$ not significant

\section{Discussion}

Soil tillage aims to provide the best conditions for plant growth and yielding, and also to keep weed infestation at the level posing no threat to crop stands (Nichols et al., 2015; Santín-Montanyá et al., 2016). A study conducted by Gruber et al. (2012) indicates that, in moderate climate, the conventional tillage system is more effective in reducing weed infestation than the no-tillage system. Also Woźniak and Kwiatkowski (2013) demonstrated significantly lesser weed infestation in the conventional tillage than in the 
reduced and herbicide systems. In contrast, in the arid Mediterranean regions, better production results and smaller weed infestation are observed in the no-tillage system compared to the conventional tillage (López-Bellido et al., 2001; De Vita et al., 2007). According to Ruisi et al. (2014), caution should be exercised to the appropriate crop rotation in the no-tillage system (NT), with cereals cultivation after themselves found as the inappropriate sequence. Also in our study, the highest barley yield was determined in CT after pea $\left(5.57 \mathrm{t} \mathrm{ha}^{-1}\right)$, whereas the lowest one - in NT after pea $\left(1.89 \mathrm{t} \mathrm{ha}^{-1}\right)$. It is due to a lower number of plants per $\mathrm{m}^{2}$ in NT than in CT, a lower spike number per $\mathrm{m}^{2}$, a lower grain weight per spike, and also a lower 1000 grain weight. The outcomes of barley cultivation after wheat included also: a lower plant number and spike number per $\mathrm{m}^{2}$, a lower grain weight per spike, and a lower 1000 grain weight than after its cultivation after pea. In the present study, values of these traits depended to a greater extent on tillage systems (TS) than on crop rotation (CR). Similar dependencies were observed by Jug et al. (2011).

The no-till systems and cereal monoculture are characterized by increased number and weight of weeds as well as by predominance and compensation of a few weed species, compared to the conventional tillage and crop rotation (Koning et al., 2019; Woźniak, 2019). As reported by Hernández Plaza et al. (2015), the NT system promotes species with fine grains and high fertility whose seeds accumulate mainly on soil surface from where they sprout under convenient conditions. According to Farooq et al. (2011), these weeds are effectively eradicated by herbicides, but the inappropriate use of these preparations may develop plant resistance to them. In turn, greater species diversity of weeds having seeds of various sizes and exhibiting various fertility is observed in the CT system (Hernández Plaza et al., 2011). During cultivation, these seeds are transferred into deeper soil layers from where only some of them are capable to sprout (Santín-Montanyá et al., 2016). Generally, it may be concluded that the conventional tillage system (ploughing) and the use of glyphosate in the no-tillage system reduce the number and weight of weeds and also affect their species composition. This has also been confirmed in the present study where a lower number of weed species and lower weed density were observed in CT and NT systems than in the RT system. Weed distribution in the crop is also of high importance. It may, generally, be concluded that weeds of the upper and the middle levels spread with wind (anemochorically) or during harvest of cereals, whereas weeds of the lower and the ground levels ripe and spread on the stubble field. In the study conducted by Woźniak (2018), 45\% of weeds identified in the herbicide tillage system were represented by species with small grains belonging to the upper and middle levels. Also in the present study, most of the weed species formed the middle and the upper layer of the crop, from where they could easily spread before the harvest of cereals.

Tillage system and crop rotation affect also soil properties (Woźniak, 2019). Soil from the cereal monoculture contains less organic matter and organic carbon (Maillard et al., 2016) than the soil from crop rotation; in addition, its biological activity decreases (Kretzschmar and Monestiez, 1992). Also in the present study, the soil sampled after pea cultivation contained more organic $\mathrm{C}$ and total $\mathrm{N}$ than the soil after wheat cultivation. More organic $\mathrm{C}$ and total $\mathrm{N}$ was also determined in the soil samples from NT and RT systems than from CT system, which is in agreement with findings reported earlier by Tabaglio et al. (2008), Zikeli et al. (2013), Santín-Montanyá et al. (2016) and Woźniak (2019). 


\section{Conclusion}

Tillage systems and crop rotation caused significant differences in grain yield of winter barley, weed infestation, and soil properties. The highest grain yield was determined for barley grown in the conventional system after pea, whereas the lowest one for barley grown in no-till system after winter wheat. Grain yield, numbers of plants and spikes per $\mathrm{m}^{2}$, and grain weight per spike depended to a larger extent on tillage systems than on crop rotation. A higher number and weight of weeds per $\mathrm{m}^{2}$ was determined in the reduced tillage system compared to the conventional and no-till systems. Also, a higher number of weeds was found on the plot where barley was sown after winter wheat than after pea. The number and weight of weeds per $\mathrm{m}^{2}$ were affected to a greater extent by tillage system than by crop rotation. Tillage systems differentiated also species number and composition of weeds. A higher number of weed species was found in the reduced tillage system than in the conventional and no-till systems. The soil sampled from plots cultivated in the notill system contained more organic $\mathrm{C}$ than the soil collected from reduced and conventional systems as well as more total $\mathrm{N}$ than from the conventional system. Likewise, more organic $\mathrm{C}$ and total $\mathrm{N}$ was found in the soil sampled from the plot where barley was sown after pea than after wheat.

\section{REFERENCES}

[1] Aziz, I., Mahmood, T., Islam, K. R. (2013): Effect of long-term no-till and conventional tillage practices on soil quality. - Soil and Tillage Research 131: 28-35.

[2] BBCH Working Group (2001): Growth stages of mono-and dicotyledonous plants. - In: Meier, U. (ed.) Federal Biological Research Centre for Agriculture and Forestry ( $2^{\text {nd }}$ ed.).

[3] Celik, I., Barut, Z. B., Ortas, I., Gok, M., Demirbas, A., Tulun, Y., Akpinar, C. (2011): Impacts of different tillage practices on some soil microbiological properties and crop yield under semi-arid Mediterranean conditions. - International Journal of Plant Production 5: 237-254.

[4] De Vita, P., Di Paolo, E., Fecondo, G., Di Fonzo, N., Pisante, M. (2007): No-tillage and conventional tillage effects on durum wheat yield, grain quality and soil moisture content in southern Italy. - Soil and Tillage Research 92: 69-78.

[5] Derpsch, R., Friedrich, T., Kassam, A., Hongwen, L. (2010): Current status of adoption of no-till farming in the world and some of its main benefits. - International Journal of Agricultural and Biological Engineering 3: 1-25.

[6] Farooq, M., Flower, K. C., Jabran, K., Wahid, A., Siddique, K. H. M. (2011): Crop yield and weed management in rainfed conservation agriculture. - Soil and Tillage Research 117: 172-183.

[7] Gawęda, D., Woźniak, A., Harasim, E. (2018): Weed infestations of winter wheat depend on the forecrop and the tillage system. - Acta Agrobotanica 71: 1744.

[8] Gruber, S., Pekrun, C., Möhring, J., Claupein, W. (2012): Long-term yield and weed response to conservation and stubble tillage in SW Germany. - Soil and Tillage Research 121: 49-56.

[9] Haliniarz, M., Nowak, A., Woźniak, A, Sekutowski, T. R., Kwiatkowski, C. A. (2018): Production and economic effects of environmentally friend.ly spring wheat production technology. - Polish Journal of Environmental Studies 27: 1523-1532.

[10] Hernández Plaza, E. H., Kozak, M., Navarrete, L., González-Andújar, J. L. (2011): Tillage system did not affect weed diversity in a 23-year experiment in Mediterranean dryland. Agriculture, Ecosystems and Environment 140: 102-105. 
[11] Hernández Plaza, E., Navarrete, L., González-Andújar, J. L. (2015): Intensity of soil disturbance shapes response trait diversity of weed communities: The long-term effects of different tillage systems. - Agriculture, Ecosystems and Environment 207: 101-108.

[12] Jug, I., Jug, D., Sabo, M., Stipešević, B., Stošić, M. (2011): Winter wheat yield and yield components as affected by soil tillage systems. - Turkish Journal of Agriculture and Forestry 35: 1-7.

[13] Koning, L. A., de Mol, F., Gerowitt, B. (2019): Effects of management by glyphosate or tillage on the weed vegetation in a field experiment. - Soil and Tillage Research 186: 7986.

[14] Kretzschmar, A., Monestiez, P. (1992): Physical control of soil biological activity due endogenic earthworm behaviour. - Soil Biology and Biochemistry 24: 1609-1614.

[15] López-Bellido, L., López-Bellido, R., Castillo, J. E., López-Bellido, F. J. (2001): Effects of long-term tillage, crop rotation and nitrogen fertilization on bread-making quality of hard red spring wheat. - Field Crops Research 72: 197-210.

[16] Maillard, É., Angers, D. A., Chantigny, M., Lafond, J., Pageau, D., Rochette, P., Lévesque, G., Leclerc, M. L., Parent, L. É. (2016): Greater accumulation of soil organic carbon after liquid dairy manure application under cereal-forage rotation than cereal monoculture. Agriculture, Ecosystems and Environment 233: 171-178.

[17] Montemurro, F., Maiorana, M. (2015): Agronomic practices at low environmental impact for durum wheat in Mediterranean conditions. - Journal of Plant Nutrition 38: 624-638.

[18] Nichols, V., Verhulst, N., Cox, R., Govaerts, B. (2015): Weed dynamics and conservation agriculture principles: A review. - Field Crops Research 183: 56-68.

[19] Rachoń, L., Szumiło, G., Brodowska, M., Woźniak, A. (2015): Nutritional value and mineral composition of grain of selected wheat species depending on the intensity of a production technology. - Journal of Elementology 20: 705-715.

[20] Ruisi, P., Giambalvo, D., Saia, S., Di Miceli, G., Frenda, A. S., Plaia, A., Amato, G. (2014): Conservation tillage in a semiarid Mediterranean environment: results of 20 years of research. - Italian Journal of Agronomy 9: 560.

[21] Santín-Montanyá, M. I., Martín-Lammerding, D., Zambranab, E., Tenorio, J. L. (2016): Management of weed emergence and weed seed bank in response to different tillage, cropping systems and selected soil properties. - Soil and Tillage Research 161: 38-46.

[22] Tabaglio, V., Gavazzi, C., Menta, C. (2008): The influence of no-till, conventional tillage and nitrogen fertilization on physico-chemical and biological indicators after three years of monoculture barley. - Italian Journal of Agronomy 3: 233-240.

[23] West, T. O., Marland, G. (2002): A synthesis of carbon sequestration, carbon emissions, and net carbon flux in agriculture: Comparing tillage practices in the United States. Agriculture, Ecosystems and Environment 91: 217-232.

[24] Woźniak, A. (2018): Effect of tillage system on the structure of weed infestation of winter wheat. - Spanish Journal of Agricultural Research 16: e1009.

[25] Woźniak, A. (2019): Effect of crop rotation and cereal monoculture on the yield and quality of winter wheat grain and on crop infestation with weeds and soil properties. - International Journal of Plant Production 13: 177-182.

[26] Woźniak, A., Kwiatkowski, C. (2013): Effect of long-term reduced tillage on yield and weeds of spring barley. - Journal of Agricultural Science and Technology 15: 1335-1342.

[27] Woźniak, A., Stępniowska, A. (2017): Yield and quality of durum wheat grain in different tillage systems. - Journal of Elementology 22: 817-829.

[28] WRB (2014): World reference base for soil resources. - World Soil Resources Reports No. 106. FAO.

[29] Zikeli, S., Gruber, S., Teufel, C. F., Hartung, K., Claupein, W. (2013): Effects of reduced tillage on crop yield, plant available nutrients and soil organic matter in a 12-year longterm trial under organic management. - Sustainability 5: 3876-3894. 